\title{
THE CONTINUOUS PROFESSIONAL DEVELOPMENTIN THE ENVIRONMENTAL FIELDUSING THE OCCUPATIONAL STANDARDS
}

\author{
Ionel Virgil Criste, Ana Anghel \\ National Research and Development Institute for Industrial Ecology, Bucharest, Drumul \\ Podu Dambovitei, no. 71-73, sector 6, postal cod 060652, \\ e-mail:ecoind@incdecoind.ro,Romania
}

\begin{abstract}
The transnational mobility of the workers on the European labour market as well of those who study implies the recognition of knowledge, skills and competences acquired in any way.

Welcoming to this need, the European Parliament and Council issued in April 2008 the Recommendation regarding the European Qualifications Framework (EQF) for learning throughout life. EQF recommends to member countries to adopt an approach based on learning outcomes to defining and describing the qualifications, and to promote the validation of non-formal and informal education.

The description of qualifications is done in occupational standards by setting and description of the required competences. The occupational standards are the references for training and for evaluation and certification of competencies. In this paper is presented the development, for authorization, of the formation program Environmental Responsible based on the same name occupational standard.

The specific competences, in line with this occupational standard achieved by learners are: managing environmental legal acts, development and implementation of environmental management program, development of the program and monitoring the environmental factors, planning and conducting the internal audit, identification and management of the emergency situations, developing the documentation of the environmental management system and reporting the environment activity.
\end{abstract}

Keywords: audit, monitoring, occupational standards, professional competencies, training program.

\section{Introduction}

The Europe 2020 strategy for smart, sustainable and inclusive growth acknowledges the lifelong learning and the acquisition of competencies as key elements in response to the current economic crisis, to the aging population and to the far-reaching economic and social strategy of the European Union.

The economic crisis has highlighted the crucial role of the adult learning in achieving the Europe 2020 goals, enabling the adults, especially low-skilled workers and the older to improve their ability to adapt to the changes in the labour market and society. The adult learning provides a means of improving the qualification or requalification of the people affected by unemployment, restructuring and/or career changes, bringing also an important contribution to social inclusion, active citizenship and personal development.

In the last decade, adult learning has occupied a central position in the European cooperation policy for education and professional formation. The European Union countries agreed that by 2020 at least $15 \%$ of adults will participate in some form of education or training. Currently only Denmark, the 
Netherlands, Finland, Sweden and the UK have exceeded this target. At present Romania reached only $2 \%$. [1]

The European Union offered a series of recommendations which relate to adopt a strategy for lifelong learning, to provide access to lifelong learning for adults with low skills. On April 23, 2008 The European Parliament and the EU Council have made the recommendations regarding the establishment of the European Qualifications Framework for lifelong learning (EQF) open and flexible, based on transparency and mutual trust, which is a common reference point for education and training.

Through this document the Parliament and the Council recommend member states "to adopt an approach based on learning outcomes for defining and describing qualifications and to promote the validation of non-formal and informal learning in accordance with the common European principles agreed in the Council conclusions of 28 May 2004" [2]. European Qualifications Framework sets out eight levels of competencies, each defined by a set of descriptors indicating the learning outcomes relevant to qualifications at that level in any system of qualifications.

"Learning outcomes means that knows, understands and is able to do a person at completion of the learning process, which are defined in terms of knowledge, skills and competencies. Knowledge means the outcome of the assimilation of information through learning. Knowledge is the body of facts, principles, theories and practices related to a particular field of work or study. In the context of the European Qualifications Framework, knowledge is described as theoretical and / or factual.

Skills means the ability to apply and use knowledge to bring to complete tasks and solve problems. In the context of the European Qualifications Framework, skills are described as cognitive (involving the use of logical, intuitive and creative thinking) or practical (involving manual dexterity and use of methods, materials, tools and instruments). Competence means the proven ability to use knowledge, skills and personal, social and/ or methodological work or study situations and for professional and personal development. In the context of the European Qualifications Framework, competence is described in terms of responsibility and autonomy" [2]

In Romania the National Qualifications Framework (NQF) sets, as the EQF, eight levels of skill that can be acquired through formal education system and professional formation in Romania and recognition of learning outcomes acquired through learning in non-formal and informal, in the light of lifelong learning. [3]

\section{Materials and Methods}

The legal basis regulating the professional training in our country includes:

- the national education law 1/2011, as amended and supplemented;

- the government decision no. 556/2011 on the organization, structure and functioning of the National Authority for Qualifications, as amended and supplemented;

- the government ordinance no. 129/2000 on adult vocational training, as amended and supplemented; 
- the government decision no. 522/2003 approving the methodological norms for implementing GO 129/2000 on adult vocational training;

- the government decision no. 918/2013 approving the National Qualifications Framework, as amended and supplemented;

- the methodology for authorizing the providers of adult vocational training, approved by OMMSSF / OMECT no. 353/5202/2003, as amended and supplemented

- the guide for development of occupational standards for education and training.

In accordance with OG 129/2000, the adult vocational training includes initial training and continuous training organized by specific forms other than the national education system.

The adult vocational training is organized by professional training programs that include: initiation, qualification, requalification, training or specialization and leads to qualification or graduation certificates with national recognition and / or certificate of competence. The professional training programs include all activities theoretical and / or practical training to achieve the objectives for a particular area of expertise, including environmental protection. [4]

The professional training programs are organized by training providers for occupations, trades, specializations and professions included in the classification of occupations in Romania - COR. In the environmental area are 22 occupations in COR, including operators, technicians and assimilated, specialists and researchers. [5]

The professional training programs ensure the acquisition of professional competencies according to occupational standards for education and training, nationally recognized.

The occupational standard is an instrument that establishes the requirements for practicing an occupation expressed by skills and competencies and includes the defining elements of education and professional training, expressed as: knowledge, qualification level, educational level, plan and program of theoretical and practical training, access and promotion conditions, personal development, certificate / diplomas, supplements to diplomas / certificates.

The new occupational standards approved by OMECS No 3170/2015 allows that education and professional training to practice an occupation, to be achieved in an unitary manner at the national level, similar to developed countries in Europe. The professional training providers may organize professional training programs completed by qualification or graduation certificate with national recognition, if they are authorized in law. The training providers' authorization is given by the National Authority for Qualifications based on evaluation criteria, for a period of four years for each of qualifications, occupations, skills groups for which the training providers organize training programs.

\section{Results and Discussion}

Environmental protection low stipulates that "the legal persons carrying out activities with significant environmental impact should organize specialized structures for environmental protection". [6] These structures are constituted 
depending on organization's scope, size and complexity and may include: departments, laboratories, services or designated persons with duties and responsibilities in environmental protection like environmental manager or environmental responsible. Environmental responsible is an occupation provided in the Occupations' Classification in Romania with code number 325710, 3level training - high school or college.

The environmental responsible must:

- know and apply the environmental legal provisions applicable in organization

- know the processes of the organization, machinery and equipment, to identify environmental issues

- coordinate the work for identifying environmental aspects and for evaluation of associated environmental impacts

- establish the environmental objectives and the environmental management program

- monitor the environmental factors

- action to reduce consumption of natural resources

- manage normative and regulatory environment acts

- manage the hazardous chemicals, waste and packaging

- develop the environmental management system documentation

- perform internal audits of the environmental management system

- coordinate the environmental training

- supervise the preparation for emergencies

- conduct environmental reporting [7].

INCD ECOIND has proposed to develop and authorize a professional training program for the occupation Environmental responsible to provide students the necessary knowledge to fulfil the principal responsibilities and attributes of the environmental responsible. For this purpose it developed a course support to ensure the full coverage of the nine specific competencies from the occupational standard Environmental responsible:

- managing of environmental normative acts

- developing of environmental management program

- developing of environmental factors monitoring program;

- monitoring the environmental factors;

- establishing the internal audit

- developing of internal audit program

- supervising the emergencies preparation

- preparing the documents for environmental management

- reporting the activity on the environment [7]

This course support contains 8 chapters, namely:

Chapter 1 - Environmental legislation

Chapter 2 - Identification of environmental aspects and assessment of associated impacts

Chapter 3 - Environmental Management System

Chapter 4 - Obtaining the regulatory acts

Chapter 5 - Obligations relating to the environment fund

Chapter 6 - Waste management

Chapter 7 - Hazardous chemicals management

Chapter 8 - Reporting the activity on the environment

For the practical application of the training materials has constituted a group of 10 people, the environmental and quality responsible from the institute, practical the environmental responsible for departments / laboratories / compartments. 
In order to authorize the professional training program Environmental responsible was prepared the documentation for authorization in accordance with the requirements of the methodology for authorizing the providers of adult's professional training (Order 353/2003 updated). For this purpose were developed documents proving that the criteria for authorization in accordance with the instructions of preparation and presentation of the documents by the training provider for authorization: self-assessment sheet, the training plan, the training curriculum, methods for assessing the participants at the training program. [8]

- Self-assessment sheet - Annex 1 to the authorization methodology which describes the professional training program:

- the program type: specialization

- the occupation and the COR code name: environmental responsible 325710

- the occupational area: environment protection

- the type of obtained certificate: graduation

- the access conditions: high school or college graduate

- the objectives expressed in the 9 professional competencies

- the duration of training: 80 hours - 25 hours for theoretical training, 55 hours for practical training

- the venue: the lecture hall and the conference room

- the form of organization: course

- number of participants per training group: for theoretical training max 20 participants, for practical training for groups of max 5 participants

- The training plan- annex 4 to the authorization methodology -the program takes place over 10 days and includes seven modules:

1. Environmental legislation and management of environmental normative acts,

2. Identification of environmental aspects and development of environmental management program,

3. Developing of monitoring program and monitoring the environmental factors,

4. Developing the internal audit program and realization of internal audit,

5. Supervision of activity to prevent the effects of emergencies,

6. Environmental management system and preparation of environmental management documentation,

7. Reporting the activity on the environment.

Table 1: The training plan

\begin{tabular}{|l|l|l|l|}
\hline Day 1 & Module I & $\begin{array}{l}2 \text { hours theory } \\
1 \text { hour theory }\end{array}$ & $\begin{array}{l}4 \text { hours practice } \\
1 \text { hour practice }\end{array}$ \\
\hline Day 2 & Module II II & 2 hours theory & 6 hours practice \\
\hline Day 3 & Module VI & 4 hours theory & 4 hours practice \\
\hline Day 4 & Module VI & 4 hours theory & 4 hours practice \\
\hline Day 5 & Module VI & - & 8 hours practice \\
\hline Day 6 & Module IV & 3 hours theory & 5 hours practice \\
\hline Day 7 & Module IV & 1 hour theory & 3 hours practice \\
& Module III & 2 hours theory & 2 hours practice \\
\hline Day 8 & Module III & - & 4 hours practice \\
& Module V & 1 hour theory & 3 hours practice \\
\hline Day 9 & Module VII & 4 hours theory & 4 hours practice \\
\hline Day 10 & Module VII & 1 hour theory & 7 hours practice \\
\hline Total & 80 hours & 25 hours & 55 hours \\
\hline
\end{tabular}


- The training curriculum - annex 2 to the authorization methodology - develops the training plan's modules

For example: the module II Identification of environmental aspects and developing the environmental management plan total 10 hours: 3 hours theory, 7 hours practice

Table 2: The training curriculum for module II

\begin{tabular}{|c|c|c|c|c|c|}
\hline $\begin{array}{l}\mathrm{Nr} . \\
\mathrm{crt} .\end{array}$ & $\begin{array}{l}\text { Specific } \\
\text { competencies }\end{array}$ & $\begin{array}{l}\text { Thematic } \\
\text { content }\end{array}$ & $\begin{array}{l}\text { Methods / } \\
\text { Activity } \\
\text { forms }\end{array}$ & $\begin{array}{l}\text { Training } \\
\text { means / } \\
\text { Learning } \\
\text { materials }\end{array}$ & Performance criteria \\
\hline 2 & \begin{tabular}{|l|} 
Developing \\
environment \\
al \\
management \\
program \\
- Identifying \\
environmental \\
aspects \\
- Selection of \\
significant \\
environmental \\
aspects \\
Establishment \\
of \\
environmental \\
objectives \\
- \\
Development \\
of \\
environmental \\
management \\
program
\end{tabular} & $\begin{array}{l}\text { Course } \\
\text { support: } \\
\text { Chapter } 2 \\
\text { Identification } \\
\text { of } \\
\text { environmenta } \\
\text { I aspects and } \\
\text { assessment } \\
\text { of associated } \\
\text { impacts }\end{array}$ & $\begin{array}{l}\text { Exposure, } \\
\text { Debate } \\
\text { Discovery } \\
\text { Case study } \\
\text { Practical } \\
\text { exercise } \\
\text { Teamwork } \\
\text { Project }\end{array}$ & $\begin{array}{l}\text { Course } \\
\text { support } \\
\text { Flipchart } \\
\text { Projector; } \\
\text { Laptop } \\
\text { Workbooks }\end{array}$ & $\begin{array}{l}\text { Identifies correctly and } \\
\text { completely in accordance } \\
\text { with legal environmental } \\
\text { requirements, based on } \\
\text { specific procedures, the } \\
\text { environmental aspects for } \\
\text { all activities in all modes of } \\
\text { operation andfor the } \\
\text { organization's products and } \\
\text { services; } \\
\text { Selects with fairness and } \\
\text { rigor in accordance with } \\
\text { legal environmental } \\
\text { requirements, based on } \\
\text { specific procedures, the } \\
\text { significant environmental } \\
\text { aspects; } \\
\text { Establish with responsibility } \\
\text { and objectivity the } \\
\text { environmental objectives, in } \\
\text { accordance with legal } \\
\text { environmental requirements } \\
\text { and the organization's } \\
\text { internal requirements; } \\
\text { Develops promptly and } \\
\text { responsibly, according to } \\
\text { internal documentation of } \\
\text { the environmental } \\
\text { management system, the } \\
\text { environmental management } \\
\text { program in compliance with } \\
\text { legal environmental } \\
\text { requirements, with the } \\
\text { measures to achieve } \\
\text { specific environmental } \\
\text { objectives and with all } \\
\text { specific organization data. }\end{array}$ \\
\hline
\end{tabular}

- Methods for assessing the participants at the training program - Annex 3 to the authorization methodology: 
a. Initial assessment to adapt the training program to the participants' needs - is achieved by selection of files (documents/records specific of careers: work experience, previous training, etc.).

b. Ongoing evaluation: assessing the participation in debates and teamwork and monitoring the responses to questions, exercises, case studies and tests - scores of 1-10 and / or qualifications.

c. Final assessment: written test (combined grille + open questions) and a practical test (case study / project), oral exam (oral presentation of the practical test + response to questions) - scores of 1-10.

Finally the application and the file for authorization were submitted to the commission for authorization. After analysing the file, the commission authorized the professional training program Environmental responsible and issued the authorization.

\section{Conclusions}

INCD ECOIND will use the professional training program Environmental responsible for training activities in the field of environmental protection, this program will complete the portfolio of institute professional training programs in the environmental area which currently has two authorized programs: Environmental Auditor and Manager of Environment Management Systems.

\section{References}

[1] Adult continuous education and training, Romanian National Authority for Qualifications, 2015, http://www.anc.edu.ro

[2] Recommendation of the European Parliament and of the Council on the establishment of the European Qualifications Framework for lifelong learning,(2008), content/EN/TXT/?uri=OJ:C:2008:111:TOC http://eur-lex.europa.eu/legal-

[3] HG no. 918 (2013) approving the National Qualifications Framework, the government of Romania, http://www.anc.edu.ro

[4] OG no. 129 (2000)on adult professional training, the government of Romania, http://www.anc.edu.ro

[5] Occupations Code in Romania (2015), http://www.rubinian.com/cor

[6] OUG 195 (2005)on environmental protection, the government of Romania,http://www.mmediu.ro

[7] Occupational Standard Environmental responsible, Sectoral Committee on Environmental Protection Training, http://www.anc.edu.ro

[8] OMMSSF/OMECT nr. 353/5.202(2003)Methodology for authorizing the providers for adult professional training, Romanian Ministry of Environment/Romanian Ministry of Education, http://www.anc.edu.ro 